\title{
Genomic Characterisation and Response to Trastuzumab and Paclitaxel in Advanced or Recurrent HER2-positive Endometrial Carcinoma
}

\author{
MARTIN KOSKAS ${ }^{1,2,3}$, JEROEN DEPREEUW ${ }^{1,4,5}$, STIJN MOENS $^{1}$, DANIELA ANNIBALI $^{1}$, \\ TINE CUPPENS $^{1}$, PHILIPPE MOERMAN $^{6}$, DIETHER LAMBRECHTS ${ }^{4,5}$ and FREDERIC AMANT ${ }^{1,7}$ \\ ${ }^{1}$ Department of Obstetrics and Gynecology, Division of Gynecologic Oncology, \\ KU Leuven - University of Leuven, University Hospitals Leuven, Leuven, Belgium; \\ ${ }^{2}$ Department of Obstetrics and Gynecology, APHP Hôpital Bichat, Diderot University Paris, Paris, France; \\ ${ }^{3}$ EA 7285, UVSQ, Montigny le Bretonneux, France; \\ ${ }^{4}$ Department of Oncology, Laboratory for Translational Genetics, KU Leuven, Leuven, Belgium; \\ ${ }^{5}$ VIB, Vesalius Research Center (VRC), Leuven, Belgium; \\ ${ }^{6}$ Department of Imaging and Pathology, Division of Translational Cell and Tissue Research, \\ KU Leuven, University of Leuven, University Hospitals Leuven, Leuven, Belgium; \\ ${ }^{7}$ Center for Gynecologic Oncology Amsterdam (CGOA), Netherlands Cancer Institute (NKI), Amsterdam, the Netherlands
}

\begin{abstract}
Background/Aim: Human epidermal growth factor receptor 2 (HER2) positivity is associated with a worse prognosis in endometrial cancer (EC). Trastuzumab as a single agent did not demonstrate activity in such cases but there are no reports on its combined use with taxanes. We report the outcome in patients treated simultaneously with trastuzumab and paclitaxel for advanced or recurrent HER2positive endometrial carcinoma and compared it to their microsatellite instability (MSI) status and PIK3CA mutational profiles. Patients and Methods: Patients with advancedor recurrent endometrial carcinoma showing HER2 overexpression $(2+$ or $3+$ immunohistochemical staining $)$ or HER2 amplification (fluorescence in situ hybridization (FISH) HER2/chromosome 17 centromere (CEP 17) ratio $>2.0)$ were treated with trastuzumab $(8 \mathrm{mg} / \mathrm{kg})$ and paclitaxel $\left(90 \mathrm{mg} / \mathrm{m}^{2}\right)$ every three weeks. Evaluation of the response was assessed according to the response evaluation criteria in solid tumors (RECIST) guidelines. Endometrial tumors, sampled before the beginning of trastuzumab, were genotyped for PIK3CA hot spot mutations using Sequenom iPLEX Assay technology. Results: Two uterine serous adenocarcinomas and
\end{abstract}

Correspondence to: Dr. Martin Koskas, Department of Obstetrics and Gynecology, CHU Bichat Claude Bernard, 46, rue HenriHuchard. 75018 Paris, France. Tel: +33 0140258080, Fax: +33 0140256757,e-mail: martin.koskas@wanadoo.fr

Key Words: Endometrial cancer, HER2 positivity, trastuzumab, paclitaxel, PIK3CA. one grade 3 endometrioid adenocarcinoma showing HER2 positivity were treated with trastuzumab and paclitaxel. Between three and seven months of treatment, the three cases showed progressive disease. The genomic analysis of the three cases showed different mutational profiles. One case was found to have MSI and had one PIK3CA mutation. The two others showed no hot spot mutation for PIK3CA. Conclusion: Even associated with paclitaxel, HER2-positive endometrial carcinomas poorly responded to trastuzumab. This report underlines the low accuracy of HER2 positivity to predict response of endometrial cancer to combined targeted therapy using trastuzumab and paclitaxel.

Type II endometrial cancer (EC), which includes uterine serous carcinoma (USC), clear cell cancer and grade-3 endometrioid carcinoma cases, typically occurs in older nonoverweight patients, is not hormone-dependent and represents a particularly aggressive type (1). Development of more effective therapeutic strategies against this rare subset of endometrial cancer is mandatory.

Trastuzumab has been developed and proven to be efficient in breast cancer overexpressing Her2/neu (2). Various groups reported Her2/neu overexpression (by immunohistochemistry (IHC)) in patients harbouring USC with rates between $20-60 \%$ and overexpression of the Her2/neu has been found to be related to a worse prognosis $(3,4)$. These findings have provided a rationale to the use of Her2/neu-targeted therapies in patients harbouring aggressive EC subtypes.

A phase II study evaluated efficacy of trastuzumab alone against advanced or recurrent HER2-positive endometrial 
Table I. Management and outcomes of patients treated by trastuzumab and paclitaxel.

\begin{tabular}{|c|c|c|c|c|c|c|c|}
\hline & Age & $\begin{array}{l}\text { Stage and type of } \\
\text { endometrial cancer }\end{array}$ & $\begin{array}{l}\text { Initial } \\
\text { surgery }\end{array}$ & $\begin{array}{c}\text { Primary adjuvant } \\
\text { therapy }\end{array}$ & $\begin{array}{l}\text { Reason for } \\
\text { trastuzumab }\end{array}$ & $\begin{array}{c}\text { IHC/FISH on } \\
\text { recurrence }\end{array}$ & $\begin{array}{l}\text { Response to } \\
\text { trastuzumab }\end{array}$ \\
\hline Case 1 & 57 & $\begin{array}{l}\text { Stage IVA (bladder and } \\
\text { rectal invasion) } \\
\text { Grade } 3 \text { Endometrioid } \\
\text { adenocarcinoma }\end{array}$ & $\begin{array}{l}\text { Hysterectomy, rectosigmoid } \\
\text { and small intestine } \\
\text { partial resection, } \\
\text { lymphadenectomy, partial } \\
\text { cystectomy and left } \\
\text { ureter resection }\end{array}$ & $\begin{array}{l}\text { FEC } 6 \text { courses } \\
\text { Disease-free } \\
\text { for } 14 \text { months } \\
\text { Carcboplatin } \\
\text { paclitaxel for } \\
5 \text { courses }\end{array}$ & $\begin{array}{l}\text { Lung metastases } \\
\text { diagnosed } 7 \\
\text { months after } \\
\text { the end of } \\
\text { carboplatin and } \\
\text { paclitaxel }\end{array}$ & $\begin{array}{c}\text { IHC 3+ } \\
\text { Ratio HER2/ } \\
\text { CEP17: } 6.08\end{array}$ & $\begin{array}{l}\text { Progression } \\
\text { after } 4 \text { courses }\end{array}$ \\
\hline Case 2 & 69 & $\begin{array}{c}\text { Stage IVB (locoregional } \\
\text { extension, lymph nodes } \\
\text { and hepatic metastasis) } \\
\text { USC }\end{array}$ & No & $\begin{array}{c}\text { Weekly carcboplatin } \\
\text { paclitaxel } \\
12 \text { courses } \\
\text { Adriamycin } 4 \text { courses }\end{array}$ & $\begin{array}{l}\text { Progression } \\
\text { disease under } \\
\text { Adriamycin }\end{array}$ & $\begin{array}{l}\text { HER2 }(3+) \\
\text { and Ratio } \\
\text { HER2/ } \\
\text { CEP17: } 10\end{array}$ & $\begin{array}{c}\text { Progression } \\
\text { after } 3 \text { courses }\end{array}$ \\
\hline Case 3 & 70 & $\begin{array}{l}\text { Stage IVB (locoregional } \\
\text { extension, bi-iliac, } \\
\text { perirectal and left } \\
\text { inguinal lymph nodes) } \\
\text { USC }\end{array}$ & No & $\begin{array}{l}\text { Carcboplatin } \\
\text { and epirubicin } \\
6 \text { courses }\end{array}$ & $\begin{array}{c}\text { Recurrence } \\
\text { one year } \\
\text { after the end } \\
\text { of chemotherapy }\end{array}$ & HER2 (3+) & $\begin{array}{l}\text { Progression } \\
\text { after } 10 \text { courses }\end{array}$ \\
\hline
\end{tabular}

USC, Uterine serous carcinoma; FEC, fluorouracil, epirubicin and cyclophosphamide; IHC, immunohistochemistry; FISH, fluorescence in situ hybridization; HER2, human epidermal growth factor receptor 2; CEP17, chromosome 17 centromere.

carcinoma: three of eight clear cell carcinomas $(38 \%)$ and 7 of 25 USCs $(28 \%)$ screened exhibited HER2 amplification compared with $7 \%(2 / 29)$ of endometrioid adenocarcinomas (4). Thirty four women were finally enrolled and no major tumor responses were observed.

However, considering that poor response to trastuzumab alone observed in advanced or recurrent HER2-positive endometrial carcinoma has also been reported in breast cancer (5), we thought important to report a series of patients who were treated with trastuzumab associated with chemotherapy. Similar to breast cancer, we expected better response rates in patients treated with this association based on the principle that the concomitant delivery of drugs with different mechanisms of action may allow for synergistic effects. Moreover, to better understand the mechanisms underlying the response to trastuzumab associated with chemotherapy, endometrial tumors were genotyped for microsatellite instability (MSI) and PIK3CA hot spot mutations.

\section{Patients and Methods}

Patients with stage IVB or recurrent endometrial carcinoma showing HER 2 overexpression (2+ or $3+$ immunohistochemical staining) or HER2 amplification (fluorescence in situ hybridization (FISH) HER2/chromosome 17 centromere (CEP 17) ratio >2.0) were treated with trastuzumab and paclitaxel. Trastuzumab and paclitaxel were delivered together, 3 x weekly, $8 \mathrm{mg} / \mathrm{kg}$ loading, $6 \mathrm{mg} / \mathrm{kg}$ maintenance dose and at a dose of $90 \mathrm{mg} / \mathrm{m}^{2}$, respectively. Evaluation of response was assessed according to response evaluation criteria in solid tumors (RECIST) guidelines.

Informed consent was obtained from the patients.
Genotyping. Trastuzumab-naïve endometrial tumors before the beginning of trastuzumab were genotyped for MSI and PIK3CA hot spot mutations. For each tumor block, an hematoxylin and eosin slide was prepared and the tumor area delineated. Tumor tissue was macro-dissected from the individual slides and DNA extraction was performed. The iPLEX technology on a Mass ARRAY Compact Analyser (Sequenom Inc., San Diego, CA, USA) was used for mutation analysis, as reported previously (6). MSI status was checked as previously described by Zhao et al. (7). Briefly, 59 mononucleotide homopolymers were assessed for single-nucleotide insertions and deletions using Sequenom Massarray. Tumors were determined as MSI if eight or more insertions or deletions were found.

\section{Results}

Three patients, aged 57 to 70 years old, diagnosed with stage IV EC, were included (Table I). One of them underwent primary surgery, while the two others received chemotherapy first. Because of recurrent disease and after verifying HER2 overexpression on recurrent tumor, the three patients received paclitaxel/trastuzumab. However, progressive disease was observed for the three cases during treatment.

The three samples had different mutation profiles. One sample showed mutations in PIK3CA gene (c.241G>A) and MSI positivity. In the two other samples no PIK3CA hot spot mutations were detected.

\section{Discussion}

In the treatment of HER2-positive breast cancer, combination therapy with chemotherapy plus trastuzumab is generally 
more effective than single-agent trastuzumab. Unfortunately, in this small series we observed no evidence of activity of trastuzumab associated with paclitaxel against HER2positive EC. Various reasons underlying resistance to trastuzumab (single or associated with chemotherapy) have been proposed in breast and EC (8).

Potential mechanisms of resistance to trastuzumab include signaling from other members of the HER family, cross talk from the insulin-like growth factor-I receptor to HER2, Met activation and increased signaling through the PI3-kinase pathway by a variety of mechanisms, including PTEN or PIK3CA gene mutation (9-11). Recently, oncogenic PIK3CA mutations have been suggested to represent biomarkers to predict response to trastuzumab in breast cancer (12). For this reason, we conducted a genomic study on PIK3CA hot spot mutations to identify possible mechanisms underlying the poor response observed and, eventually, novel strategies for overcoming trastuzumab resistance.

USC have ERBB2 amplification in $27 \%$ of tumors and PIK3CA mutations in $42 \%$, which could provide other or combined translational opportunities for targeted therapeutics (13). In our series, we observed different genetic profiles for PIK3CA hotspot mutations. Since no response was observed for those cases, the present results suggest that identification of responders to Herceptin ${ }^{\circledR}$ and paclitaxel should not focus only on these mutations. p95HER2, a truncated variant of HER2 that lacks the extracellular domain (ECD) where trastuzumab binds, has been suggested to be involved in trastuzumab resistance in breast cancer (14). Prospective trials are underway to validate p95HER2 expression as a biomarker associated with response to specific HER2 therapies (15).

In conclusion, the present series suggests that, even associated with taxanes, trastuzumab has poor efficacy in patients with advanced HER2-positive endometrial cancer. Hopefully, development of new target therapy able to overcome inherent resistance to anti-HER2 therapy in endometrial cancer will improve prognosis for this aggressive disease.

\section{Funding}

No funding source.

\section{Conflicts of Interest}

The Authors report no financial or commercial conflicts of interest. No financial support was received for this study. The Authors have nothing to disclose.

\section{References}

1 Amant F, Mirza MR, Koskas M and Creutzberg CL: Cancer of the corpus uteri. Int J Gynaecol Obstet 131: 96-104, 2015.
2 Baselga J, Carbonell X, Castañeda-Soto NJ, Clemens M, Green M, Harvey V, Morales S, Barton C and Ghahramani P: Phase II study of efficacy, safety, and pharmacokinetics of trastuzumab monotherapy administered on a 3 -weekly schedule. J Clin Oncol 23: 2162-2171, 2005.

3 Morrison C, Zanagnolo V, Ramirez N, Cohn DE, Kelbick N, Copeland L, Maxwell GL and Fowler JM: HER-2 is an independent prognostic factor in endometrial cancer: Association with outcome in a large cohort of surgically staged patients. J Clin Oncol 24: 2376-2385, 2006.

4 Fleming GF, Sill MW, Darcy KM, McMeekin DS, Thigpen JT, Adler LM, Berek JS, Chapman JA, DiSilvestro PA, Horowitz IR and Fiorica JV: Phase II trial of trastuzumab in women with advanced or recurrent, HER2-positive endometrial carcinoma: A Gynecologic Oncology Group study. Gynecol Oncol 116: 15-20, 2010.

5 Cobleigh MA, Vogel CL, Tripathy D, Robert NJ, Scholl S, Fehrenbacher L, Wolter JM, Paton V, Shak S, Lieberman G and Slamon DJ: Multinational study of the efficacy and safety of humanized anti-HER2 monoclonal antibody in women who have HER2-overexpressing metastatic breast cancer that has progressed after chemotherapy for metastatic disease. J Clin Oncol 17: 2639-2648, 1999.

6 Garcia-Dios DA, Lambrechts D, Coenegrachts L, Vandenput I, Capoen A, Webb PM, Ferguson K; ANECS, Akslen LA, Claes B, Vergote I, Moerman P, Van Robays J, Marcickiewicz J, Salvesen HB, Spurdle AB and Amant F: High-throughput interrogation of PIK3CA, PTEN, KRAS, FBXW7 and TP53 mutations in primary endometrial carcinoma. Gynecol Oncol 128: 327-334, 2013.

7 Zhao H, Thienpont B, Yesilyurt BT, Moisse M, Reumers J, Coenegrachts L, Sagaert X, Schrauwen S, Smeets D, Matthijs G, Aerts S, Cools J, Metcalf A, Spurdle A; ANECS, Amant F and Lambrechts D: Mismatch repair deficiency endows tumors with a unique mutation signature and sensitivity to DNA doublestrand breaks. eLife 3: e02725, 2014.

8 Diver EJ, Foster R, Rueda BR and Growdon WB: The therapeutic challenge of targeting HER2 in endometrial cancer. The Oncologist 20: 1058-1068, 2015.

9 Lu CH, Wyszomierski SL, Tseng LM, Sun MH, Lan KH, Neal CL, Mills GB, Hortobagyi GN, Esteva FJ and Yu D: Preclinical testing of clinically applicable strategies for overcoming trastuzumab resistance caused by PTEN deficiency. Clin Cancer Res 13: 5883-5888, 2007.

10 Kang S, Seo SS, Chang HJ, Yoo CW, Park SY and Dong SM: Mutual exclusiveness between PIK3CA and KRAS mutations in endometrial carcinoma. Int J Gynecol Cancer 18: 1339-1343, 2008.

11 Groeneweg JW, Hernandez SF, Byron VF, DiGloria CM, Lopez H, Scialabba V, Kim M, Zhang L, Borger DR, Tambouret R, Foster R, Rueda BR and Growdon WB: Dual HER2 targeting impedes growth of HER2 gene-amplified uterine serous carcinoma xenografts. Clin Cancer Res 20: 6517-6528, 2014.

12 Majewski IJ, Nuciforo P, Mittempergher L, Bosma AJ, Eidtmann H, Holmes E, Sotiriou C, Fumagalli D, Jimenez J, Aura C, Prudkin L, Díaz-Delgado MC, de la Peña L, Loi S, Ellis C, Schultz N, de Azambuja E, Harbeck N, Piccart-Gebhart M, Bernards R and Baselga J: PIK3CA mutations are associated with decreased benefit to neoadjuvant human epidermal growth factor receptor 2-targeted therapies in breast cancer. J Clin Oncol 33: 1334-1339, 2015. 
13 Cancer Genome Atlas Research Network, Kandoth C, Schultz N, Cherniack AD, Akbani R, Liu Y, Shen H, Robertson AG, Pashtan I, Shen R, Benz CC, Yau C, Laird PW, Ding L, Zhang W, Mills GB, Kucherlapati R, Mardis ER and Levine DA: Integrated genomic characterization of endometrial carcinoma. Nature 497: 67-73, 2013.

14 Scaltriti M, Rojo F, Ocana A, Anido J, Guzman M, Cortes J, Di Cosimo S, Matias-Guiu X, Ramon y Cajal S, Arribas J and Baselga J: Expression of p95HER2, a truncated form of the HER2 receptor, and response to anti-HER2 therapies in breast cancer. J Natl Cancer Inst 99: 628-638, 2007.
15 Han SW, Cha Y, Paquet A, Huang W, Weidler J, Lie Y, Sherwood T, Bates M, Haddad M, Park IH, Oh DY, Lee KS, Im SA, Bang YJ, Ro J and Kim TY: Correlation of HER2, p95HER2 and HER3 expression and treatment outcome of lapatinib plus capecitabine in her2-positive metastatic breast cancer. PloS one 7: e39943, 2012.

Received August 18, 2016

Revised September 2, 2016

Accepted September 5, 2016 